\title{
Restoring diversity after cattail expansion: disturbance, resilience, and seasonality in a tropical dry wetland
}

\author{
Michael J. Osland, ${ }^{1,3,5}$ Eugenio González, ${ }^{2,4}$ and Curtis J. Richardson ${ }^{1}$ \\ ${ }^{1}$ Duke University Wetland Center, Nicholas School of the Environment, Durham, North Carolina 27708 USA \\ ${ }^{2}$ Organization for Tropical Studies, Palo Verde Biological Station, Bagaces, Costa Rica \\ ${ }^{3}$ U.S. Environmental Protection Agency, Gulf Ecology Division, Gulf Breeze, Florida 32561 USA \\ ${ }^{4}$ Texas A\&M University, Soltis Center for Research and Education, San Isidro de Peñas Blancas, \\ La Fortuna de San Carlos, Costa Rica
}

\begin{abstract}
As the human footprint expands, ecologists and resource managers are increasingly challenged to explain and manage abrupt ecosystem transformations (i.e., regime shifts). In this study, we investigated the role of a mechanical disturbance that has been used to restore and maintain local wetland diversity after a monotypic regime shift in northwestern Costa Rica [specifically, an abrupt landscape-scale cattail (Typha) expansion]. The study was conducted in Palo Verde Marsh (Palo Verde National Park; a RAMSAR Wetland of International Importance), a seasonally flooded freshwater wetland that has historically provided habitat for large populations of wading birds and waterfowl. A cattail ( $T$. domingensis) expansion in the 1980s greatly altered the plant community and reduced avian habitat. Since then, Typha has been managed using a form of mechanical disturbance called fangueo (a Spanish word, pronounced "fahn-gay-yo" in English). We applied a Typha removal treatment at three levels (control, fangueo, and fangueo with fencing to exclude cattle grazing). Fangueo resulted in a large reduction in Typha dominance (i.e., decreased aboveground biomass, ramet density, and ramet height) and an increase in habitat heterogeneity. As in many ecosystems that have been defined by multiple and frequent disturbances, a large portion of the plant community regenerated after disturbance (via propagule banking) and fangueo resulted in a more diverse plant community that was strongly dictated by seasonal processes (i.e., distinct wet- and dry-season assemblages). Importantly, the mechanical disturbance had no apparent short-term impact on any of the soil properties we measured (including bulk density). Interestingly, low soil and foliar N:P values indicate that Palo Verde Marsh and other wetlands in the region may be nitrogen limited. Our results quantify how, in a cultural landscape where the historical disturbance regime has been altered and diversity has declined, a mechanical disturbance in combination with seasonal drought and flooding has been used to locally restrict a clonal monodominant plant expansion, create habitat heterogeneity, and maintain plant diversity.
\end{abstract}

Key words: clonal plant; Costa Rica; invasive plant management; mechanical disturbance; nitrogen limitation; N:P stoichiometry; Palo Verde National Park; regime shift; seasonal flooding and drought; seed bank; Typha domingensis; wetland restoration.

\section{INTRODUCTION}

In the last several decades, human actions have been increasingly linked to abrupt and dramatic ecosystem transformations across large spatial scales in a variety of terrestrial, aquatic, and marine ecosystems (i.e., regime shifts [Scheffer and Carpenter 2003, Folke et al. 2004]). Since these transformations greatly alter the structure and functioning of ecosystems and the support of important ecosystem services, there has been much discussion about appropriate approaches for managing these transformed ecosystems and the potential for restoration after a regime shift (Suding et al. 2004, Hobbs and Suding 2009). Regime shifts often produce

Manuscript received 5 June 2009; revised 20 July 2010; accepted 5 August 2010. Corresponding Editor: J. C. Callaway.

${ }^{5}$ E-mail: osland.michael@epa.gov ecosystems with positive feedbacks and properties that enhance stability and resilience. As a result, ecosystem management after a regime shift is sometimes unpredictable and often entails the development and application of innovative approaches (Suding et al. 2004, Seastedt et al. 2008, Hobbs et al. 2009). In this study, we investigate the role of a mechanical disturbancebased management approach (called fangueo; description in subsequent paragraphs) that has been used to restore and maintain diversity after a monotypic regime shift (specifically an abrupt landscape-scale cattail expansion) in northwestern Costa Rica. Our investigation examines the impact of repeated disturbance and seasonality on the plant community in an ecosystem where high diversity has historically been maintained by multiple and frequent disturbances. 
Globally, cattail species are among the most ubiquitous, competitive, and invasive emergent plants in freshwater wetland ecosystems. The rapid expansion of cattail (Typha spp.; Typhaceae) into wetlands historically not dominated by cattail has occurred across the globe in response to various natural and anthropogenic perturbations (e.g., nutrient enrichment, altered hydroperiod, reduced salinity, altered sedimentation rates, non-native genotype introductions) (Galatowitsch et al. 1999, Zedler and Kercher 2004, Richardson 2008a, Travis et al. 2010). Many of these cattail expansions have occurred fast enough and at a large enough scale to be called regime shifts (see Gunderson 2001, Hagerthey et al. 2008). Due to Typha's potential for rapid dispersal, establishment, and clonal growth, in combination with the positive feedbacks associated with high litter production (Farrer and Goldberg 2009, Tuchman et al. 2009, Vaccaro et al. 2009), Typha expansion typically produces stable monodominant plant communities that support different ecosystem functions and services than those present prior to expansion (Richardson 2008a). During cattail expansion, Typha can be both the passenger of change (i.e., invasion caused primarily by environmental change with minimal species interaction) and the driver of change (i.e., invasion caused primarily by species interactions with subsequent environmental change; see discussion in Farrer and Goldberg [2009]) (sensu MacDougall and Turkington 2005). Hence, efforts to manage cattail are often complex and have challenged natural resource managers for many decades (Nelson and Dietz 1966, Linde et al. 1976, Apfelbaum 1985, Kostecke 2002). There is much interest in novel approaches that can be used at the local level to reduce the dominance of monodominant clonal plants like Typha, increase diversity, and restore wetland ecosystem conditions.

The freshwater wetlands within and adjacent to Palo Verde National Park (PVNP; northwestern Costa Rica) are among the most ecologically important and diverse wetland complexes in Central America; together, these wetlands have been designated a Ramsar Wetland of International Importance, primarily due to the important habitat that they have historically provided for large concentrations of waterfowl and wading birds. We refer to these wetlands as tropical dry wetlands to highlight the climatic drivers that shape these ecosystems (specifically distinct and extreme seasonal flooding and drought; for readers who might be more familiar with tropical dry forests, these wetlands occupy the lower portions of the same landscapes that contain tropical dry forests [Holdridge 1967]). In the 1980s, a regime shift occurred within a large freshwater wetland in PVNP (Palo Verde Marsh) that greatly altered the historic wetland regime and the habitat available to support avian populations. The historic regime (a heterogeneous landscape containing patches of open water, freefloating and floating-rooted aquatic vegetation, and predominantly short emergent vegetation [see McCoy and Rodriguez 1994, Trama 2005, Trama et al. 2009]) was rapidly converted to an expansive cattail monoculture. The cause of the sudden and dramatic Typha expansion has most often been attributed to a reduction in cattle grazing (i.e., the cattle actually eat young Typha shoots and trample vegetation; thus, this hypothesis contends that cattle grazing prevented competitive exclusion [McCoy and Rodriguez 1994, Burnidge 2000]). Although this is a plausible explanation and similar results have been observed in several other seasonally flooded and historically grazed tropical wetlands (Middleton 1999), rigorous tests of this hypothesis at Palo Verde Marsh have never been implemented and debate regarding the importance of grazing intensity continues. Furthermore, historic abiotic conditions throughout the watershed were also greatly altered during this period (see discussions in Peters [2001], Trama [2005], Daniels and Cumming [2008], Powers et al. [2009]), and other potential causal factors that have been mentioned but not conclusively examined include altered hydroperiod (González 2002, Jiménez et al. 2003), reduced salinity, increased nutrient inputs, altered fire regimes, and Typha hybridization.

In grasslands and other cultural landscapes throughout the world, repeated disturbance in the form of mowing and grazing is often used to simulate historic herbivory rates, reduce the biomass of competitive dominant tall plants, and increase plant diversity (Collins et al. 1998, Bakker and Berendse 1999, Maron and Jefferies 2001). Annual mowing is used effectively to remove plant biomass and increase plant diversity in many European floodplains (Grootjans et al. 2002, Gerard et al. 2008). In Central Mexican wetlands, $T$. domingensis is repeatedly harvested for weaving, fodder, and fertilizer, a sustainable process that results in higher plant diversity and a source of income for local communities (Hall et al. 2008, Hall 2009). In Palo Verde Marsh, Typha has been managed with a unique form of repeated disturbance called fangueo (a Spanish word, pronounced "fahn-gay-yo" in English). Fangueo is a mechanical disturbance technique used locally in northwestern Costa Rica during rice farming to control weeds and also reduce water infiltration via increased soil compaction. See McCoy and Rodriguez (1994) for a discussion of how the fangueo method was first used to restrict Typha expansion in PVNP wetlands. In the context of this study, we use the term fangueo to refer to the use of a tractor with metal paddle wheels to crush and locally remove Typha in standing water (see photographs in Fig. 1a, b, c). During the first pass of a fangueo tractor, Typha ramets are crushed and crimped, which limits oxygen transport (McCoy and Rodriguez 1994). During subsequent passes, the Typha ramets and parts of the rhizome are typically pulled up, temporarily dragged behind the tractor, and locally removed. After fangueo treatment, stresses associated with lack of oxygen due to flooding during the wet season and a lack of water availability during the dry season will 


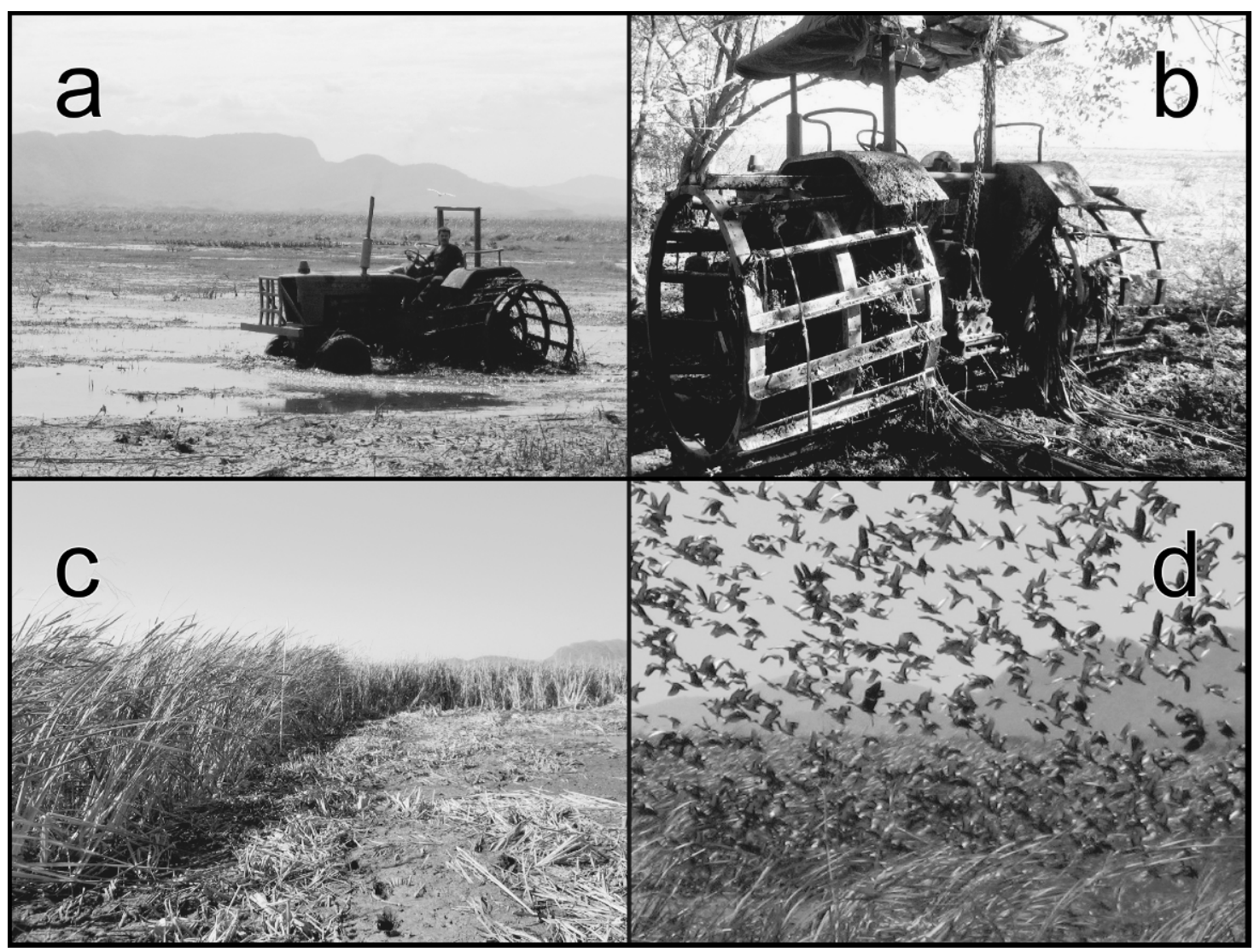

FIG. 1. Photos from Palo Verde Marsh, Palo Verde National Park, Costa Rica, depicting: (a, b) a tractor with metal paddle wheels used to remove Typha via a mechanical disturbance that is called fangueo; (c) the edge of a plot where Typha was removed via fangueo, and (d) migratory birds utilizing and flying away from a plot where Typha was removed via fangueo. Most of the individuals in the last photo are Black-bellied Whistling Ducks (Dendrocygna autumnalis), which were especially numerous after Typha removal (photo credits: M. J. Osland).

typically lead to Typha mortality. The visual impact of fangueo on avian visitation, aerial cover classes, and the creation of desirable avian habitat in PVNP is dramatic and extremely effective (McCoy and Rodriguez 1994, Trama 2005, Trama et al. 2009) (see Fig. 1d). Yet, as in most Typha removal efforts, an intensive field-based assessment of the impact of fangueo on the plant community, Typha dominance, and other ecosystem properties has not been conducted.

In this investigation we tested the following hypotheses related to the potential for restoring diversity after cattail expansion in Palo Verde Marsh: (1) the physical disturbance and potential compaction associated with fangueo (i.e., tractor use in a wetland) will have a detrimental impact on soil properties and seedling emergence; (2) management via a novel form of mechanical disturbance (fangueo) will rapidly reduce cattail dominance in the short term (i.e., the first year); (3) since the historic plant community has been shaped by frequent disturbances and distinct and extreme seasonal flooding and drought cycles, the previous plant community contains regenerative properties (i.e., a propagule bank) that will enable rapid reestablishment of a diverse plant community in response to Typha removal and seasonal hydrology (i.e., flooding and drawdown); and (4) the rapid landscape-scale cattail expansion has enhanced cattail stability and resilience, and despite a dramatic short-term decrease in Typha dominance and an increase in plant diversity, Typha will eventually (e.g., after 2-4 years) reestablish in the absence of additional restorative efforts (e.g., repeated disturbance). To test these hypotheses, we measured the impact of fangueo on several important soil physical and chemical properties and seedling emergence. We also quantified the impact of Typha removal on the plant community with an emphasis on the impact of seasonality and measurements that relate to Typha resistance and resilience (i.e., Typha seed bank, in situ recruitment, vertical growth, and clonal expansion).

\section{Methods \\ Study site}

This study was conducted in Palo Verde Marsh, within PVNP. PVNP is located in the Province of Guanacaste in the lowlands of the Tempisque River 


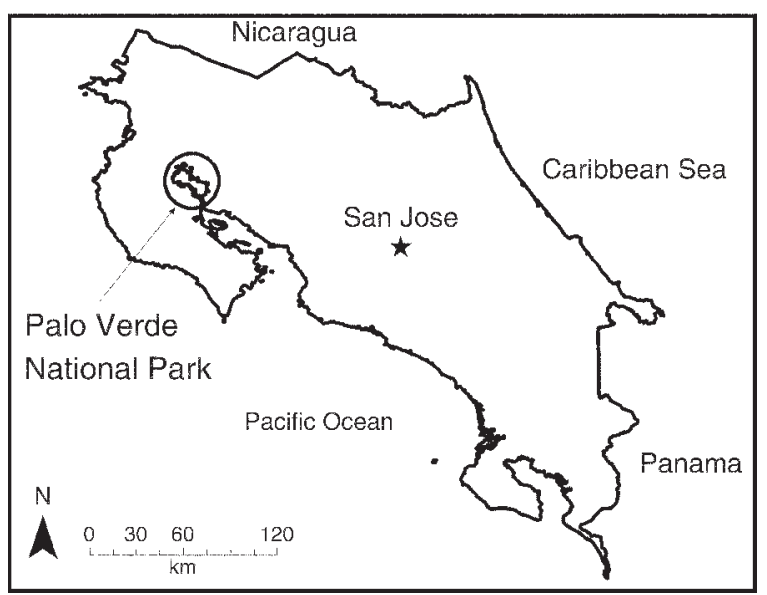

FIG. 2. Map of Costa Rica identifying the location of Palo Verde National Park.

Watershed in northwestern Costa Rica (Fig. 2). The climate in this part of Costa Rica is tropical and very seasonal. The wetlands of PVNP are collectively designated a RAMSAR Wetland of International Importance and cover an estimated 9880 ha of the total 18 800-ha area included in the park (J. Serrano, personal communication). The Organization for Tropical Studies (OTS) manages a biological station (Palo Verde Biological Station) which is within the park and immediately adjacent to Palo Verde Marsh.

Ecosystem processes in the region's freshwater wetlands are defined by seasonal flooding and drawdown associated with wet and dry seasons. Palo Verde Marsh $\left(\sim 1250\right.$ ha; $\left.10^{\circ} 20^{\prime} 35^{\prime \prime} \mathrm{N}, 85^{\circ} 20^{\prime} 25^{\prime \prime} \mathrm{W}\right)$, fills with water during the wet season $(\sim$ May-November) to a typical maximum depth of $\sim 1.5 \mathrm{~m}$. Most of these hydrologic inputs are due to surface water runoff from the adjacent forest during the wet season. However, in some years, tropical storm activity at the end of the wet season (typically in September or October) will produce water levels in excess of $1.5 \mathrm{~m}$ at the site as the Tempisque River rises higher than the natural levees and causes widespread flooding. During the dry season ( $\sim$ December-May), the water level gradually recedes due to high evapotranspiration rates that exceed the rainfall. At the end of the dry season, much of the wetland has no standing water. However, small precipitation events during the last few months of the dry season (March-April) in some years will delay and sometimes prevent complete drawdown in the wetlands. The soils in most of the wetlands within and adjacent to PVNP (including Palo Verde Marsh) are Vertisols (Loaiciga and Robinson 1995), which expand in the wet season and contract during the dry season, forming a relatively uniform and deep A horizon. Extensive cracking during the dry season (especially in areas without vegetation) promotes the mixing of this layer as pieces from the surface fall into cracks. The shrink-swell qualities of Vertisols typically enable them to recover from compaction (Sarmah et al. 1996). At present, the soil properties at the site are not well documented in the literature.

The range in total annual precipitation at the site is large. Between 1997-2007, the mean \pm SE, minimum, and maximum annual cumulative precipitation for a hydrologic year (April-March) were $1271 \pm 131 \mathrm{~mm}$, $717 \mathrm{~mm}$, and $2201 \mathrm{~mm}$, respectively (data obtained from on-site OTS records). For a longer time period (19211999), the mean annual precipitation for the entire Tempisque River Watershed was estimated to be 1817 $\mathrm{mm}$ (Mateo-Vega 2001). The mean $\pm \mathrm{SE}$ annual temperature at the site between 1997 and 2007 was $28.1^{\circ} \pm 0.3^{\circ} \mathrm{C}$. The coldest months were at the end of the wet season (September and October), with a mean temperature of $26.8^{\circ} \pm 0.2^{\circ} \mathrm{C}$. The warmest months were at the end of the dry season (March and April) with a mean temperature of $29.7^{\circ} \pm 0.2^{\circ} \mathrm{C}$.

\section{Experimental design}

Since the hydrologic and edaphic spatial variability at the site was unknown when we began the study, and potentially heterogeneous, we selected a randomized complete block design for this investigation. Within 15 blocks, a Typha removal treatment was applied at three levels (Control [C], Typha removed via fangueo [F], and Typha removed via fangueo and plot fenced $[\mathrm{FF}]$ to exclude cattle grazing). Whereas the cattail in the $\mathrm{C}$ plots was not removed, the cattail in the F and FF plots was removed via fangueo. The FF plots were also enclosed by a barbed wire fence in order to restrict cattle access and assess the additional impact of grazing after fangueo on the vegetation. Typha removal via fangueo was conducted in early February 2007. Within each block, the three treatment levels were each randomly assigned to $20-\mathrm{m}^{2}$ plots with at least $5-\mathrm{m}$ buffers on all sides (a total of $4520-\mathrm{m}^{2}$ plots). Within each $20-\mathrm{m}^{2}$ plot, three 1$\mathrm{m}^{2}$ permanent quadrats were randomly established for vegetation surveys (a total of $1351-\mathrm{m}^{2}$ quadrats). The relative water depth of each plot was determined during wet-season surveys (Table 1).

\section{Soil}

Within each of the C and F $20-\mathrm{m}^{2}$ plots, two soil samples to $10-\mathrm{cm}$ depth were collected during the first month after fangueo. Due to logistical constraints, we did not collect soil samples from the FF plots. One sample was used to determine bulk density (BD) and soil organic matter (SOM), and the other was used for total nitrogen (TN), total carbon (TC), and total phosphorus (TP) analyses. To minimize compaction, soil samples were collected by gently pounding a lightweight stainless steel piston core liner with a sharpened tip into the soil using a 680-g dead blow hammer. After collection, samples were stored at $4^{\circ} \mathrm{C}$ in sealed plastic bags at the OTS Palo Verde Biological Station until transport to the Duke University Wetland Center for analysis. Samples to be analyzed for TN, TP, and TC were dried, 
TABLE 1. A timeline of when the response variables were measured after removal of Typha via fangueo.

\begin{tabular}{ll}
\hline \hline \multicolumn{1}{c}{ Response variable } & \multicolumn{1}{c}{ Time of measurement } \\
\hline Soil properties & first month \\
Seedling emergence & third month (monitored for subsequent five months) \\
Plant community composition & second, third, and fourth month (first dry season) \\
& fifth and eighth month (first wet season) \\
Typha dominance and expansion & 15th month (second dry season) \\
& third month (first dry season) \\
& 15th month (second dry season) \\
\hline
\end{tabular}

homogenized into fine powder via a mixer mill, and passed through a $2-\mathrm{mm}$ sieve. SOM was determined using the loss on ignition method (Karam 1993). TN and TC were measured via dry combustion using a $\mathrm{CHN}$ autoanalyzer (McGill and Figueiredo 1993, Tiessen and Moir 1993). TP was measured after nitric-perchloric acid digestion (Sommers et al. 1970) using an automated ascorbic acid method (Murphy and Riley 1962) on a Lachat autoanalyzer (O'Halloran 1993). Soil and Typha foliar (i.e., live culms) N:P ratios on a mass basis were calculated to gauge nutrient limitation (Koerselman and Meuleman 1996, Verhoeven et al. 1996, Bedford et al. 1999). We measured the soil $\mathrm{pH}$ of a subset of five samples in dilute salt solution $\left(0.01 \mathrm{~mol} / \mathrm{L} \mathrm{CaCl}_{2}\right)$ (Hendershot and Lalande 1993).

\section{Seed bank}

A seedling emergence experiment was established with the following factors: Typha removal via fangueo (using the $\mathrm{C}$ and $\mathrm{F}$ plots) and water level (drawdown, flooded). Due to logistical constraints, we did not collect soil samples from the FF plots. Two sets of duplicate composite cores were collected from each of the $\mathrm{C}$ and $\mathrm{F}$ treatment plots. Each composite contained 11 cores (5$\mathrm{cm}$ depth, 4.6-cm diameter each; a total of 660 precomposite cores; total volume and area for each composite sample was $914 \mathrm{~cm}^{3}$ and $183 \mathrm{~cm}^{2}$, respectively). Each composite was mixed and placed in a $2-\mathrm{cm}$ layer on top of a $5-\mathrm{cm}$ layer of sterilized potting soil in flats with the following dimensions: $25 \mathrm{~cm}$ long $\times 20 \mathrm{~cm}$ wide $\times 10 \mathrm{~cm}$ deep. Each duplicate was assigned to one of two water level treatments: flooded or drawdown. The water level in the flooded flats was maintained $3 \mathrm{~cm}$ above the soil surface, and the drawdown flats were kept moist but not flooded. This study was conducted in a lath house at the OTS Palo Verde Biological Station. In order to account for contaminant seeds, eight control trays (i.e., trays with just the 5 -cm layer of sterilized potting soil; four drawdown and four flooded) were included in the experimental design. However, we lost two controls due to an iguana that repeatedly defecated from the lath house roof above these trays, preventing any potential germination. Emerging seedlings were identified and counted on seven dates between May and September 2007.

\section{Plant community}

Vegetation data were collected within each $1-\mathrm{m}^{2}$ quadrat at various time intervals (Table 1). In order to quantify the postdisturbance Typha recruitment potential, the number of Typha seedlings present in each $1-\mathrm{m}^{2}$ quadrat was recorded during these vegetation surveys. The cover data were used to calculate species richness and diversity (using the Shannon-Wiener index with the use of the relative percentage cover of species $i$ to represent $p_{\mathrm{i}}$ in the calculations). In order to gauge species dominance, we used the percent cover values to calculate importance values (IV), calculated as: IV = (mean percentage cover $\times$ frequency)/100. We also calculated seasonal indicator values for the standing vegetation species via indicator species analysis (INSPAN) (Dufrene and Legendre 1997) using PCORD Version 4 (MjM Software, Gleneden Beach, Oregon, USA) (McCune and Medford 1999). Indicator values represent the percentage of perfect indication of a species for a given group. In our analyses, indicator values reflect the faithfulness (i.e., constancy of presence; see McCune and Grace 2002) of a species to the dry or wet-season plant community.

Typha ramet density, height, and perpendicular basal diameters were measured within each $1-\mathrm{m}^{2}$ quadrat in April 2007 and 2008. Aboveground Typha biomass was determined using an allometric relationship we developed (sensu Miao et al. 2008) using biomass, leaf height, and elliptical basal area measurements from 148 ramets. These measurements produced the following equation $\left(r^{2}=0.97\right)$ which was used to calculate Typha aboveground biomass within each plot.

$$
\begin{aligned}
\ln (\text { aboveground biomass })= & -5.729 \\
& +0.420 \times \ln (\text { basal area }) \\
& +1.281 \times \ln (\text { height }) .
\end{aligned}
$$

In order to quantify annual cattail horizontal rhizome expansion and gauge the potential for expansion into recently managed areas, $1510-\mathrm{m}$ permanent transects were established on the edges between the $\mathrm{C}$ and $\mathrm{F}$ plots. The distance from the edges to the furthest cattail ramet was measured at 2-m intervals during the 2007 and 2008 dry season. However, on two of these transects, cattail recruitment and growth was so extensive that we could not determine the limit of vegetative expansion. Hence, 
TABLE 2. Effect of mechanical disturbance (i.e., fangueo) on soil properties (mean $\pm \mathrm{SE}$ ) at the site.

\begin{tabular}{lcc}
\hline \hline $\begin{array}{c}\text { Soil } \\
\text { properties }\end{array}$ & $\begin{array}{c}\text { No mechanical } \\
\text { disturbance }\end{array}$ & $\begin{array}{c}\text { Mechanical } \\
\text { disturbance }\end{array}$ \\
\hline $\mathrm{BD}\left(\mathrm{g} / \mathrm{cm}^{3}\right)$ & $1.02 \pm 0.03$ & $0.95 \pm 0.06$ \\
$\mathrm{SOM}(\mathrm{g} / \mathrm{kg})$ & $99 \pm 7$ & $108 \pm 14$ \\
$\mathrm{TC}(\mathrm{g} / \mathrm{kg})$ & $39.4 \pm 3.8$ & $48.1 \pm 8.3$ \\
$\mathrm{TN}(\mathrm{g} / \mathrm{kg})$ & $3.5 \pm 0.3$ & $3.9 \pm 0.6$ \\
$\mathrm{TP}(\mathrm{mg} / \mathrm{kg})$ & $529 \pm 53$ & $545 \pm 36$ \\
$\mathrm{C}: \mathrm{N}(\mathrm{mass})$ & $11.4 \pm 0.5$ & $12.0 \pm 0.6$ \\
$\mathrm{~N}: \mathrm{P}$ (mass) & $6.8 \pm 0.5$ & $7.0 \pm 0.9$
\end{tabular}

Note: There was no significant impact of fangueo on any of the properties measured. Key to abbreviations: BD, bulk density; SOM, soil organic matter.

these two transects were not measured and the results from the remaining 13 transects are presented here.

\section{Data analyses}

To assess the impact of mechanical disturbance on the measured soil and seed bank dependent variables, we used univariate mixed factor analyses of variance (ANOVA) models with block as a random effect and mechanical disturbance as a fixed effect. For the seed bank analyses, water level was also added to the model as a fixed effect. For the analyses, seed density and soil TP, TN, TC, and SOM were log-transformed to improve normality. The soil and seed bank response variables were only measured for two levels of the Typha removal treatment $(\mathrm{C}$ and $\mathrm{F})$ and, hence, means were compared using Student's $t$ tests.

To compare Typha stand characteristic (Typha ramet density, height, and aboveground biomass) differences and plant diversity and richness in response to Typha removal, we used repeated measures mixed factor effects ANOVA models with the following independent variables: block (random effect), time (fixed effect), Typha removal (fixed effect), and the interaction between time and Typha removal. Typha data were collected from all three Typha removal treatment levels for this analysis. So, comparisons of means between treatments within years and between years within treatments were conducted using Tukey's Studentized Range (HSD) tests and repeated measures $t$ tests, respectively. All ANOVA analyses were conducted using SAS Version 9.1.3 (SAS 2004).

To illustrate changes in plant community composition due to the Typha removal treatments, a nonmetric multidimensional scaling (NMS) analysis (Kruskal 1964, Mather 1976, McCune and Grace 2002) was performed using PC-ORD (McCune and Medford 1999). Prior to analysis, we relativized the species cover data by species maxima and removed rare species, which were defined as species present in $<5 \%$ of the plots. We also removed one plot survey that had zero plants present. The resultant matrix contained 20 species and 251 plots. Bray-Curtis dissimilarity coefficients were used to quantify plant species compositional distance (Bray and Curtis 1957). In order to determine the appropriate number of dimensions to include in the analysis, we used a stepdown procedure to compare the number of dimensions with the corresponding change in final ordination stress. We initially evaluated six axes using 100 runs with real data, a stability criterion of 0.00001 , a maximum of 400 iterations, and a Monte Carlo test with 300 randomizations to determine whether the resultant axes were stronger than those identified by chance (McCune and Grace 2002). Based upon this procedure, a three-dimensional analysis was deemed optimal and resulted in a final stress of 17.1, a $P$ value of 0.001 , and a final instability of 0.00001 after 219 iterations. Multi-response permutation procedures (MRPP) were then used to compare the treatment effect on plant community composition within and between dates. For all MRPP analyses, we used Bray-Curtis dissimilarity as the distance measure and $n /(\operatorname{sum} n)$ to weight groups.

\section{Results}

Soil

There was no significant impact of mechanical disturbance (i.e., fangueo) on bulk density or any of the soil properties we measured (Table 2). Of the soil properties measured, the blocking factor was only significant for total phosphorus (TP) $\left(F_{14,14}=4.3, P<\right.$ 0.01 ), which had a wide range in values; the median, minimum, and maximum TP were $473 \mathrm{mg} / \mathrm{kg}, 357 \mathrm{mg} /$ $\mathrm{kg}$, and $1114 \mathrm{mg} / \mathrm{kg}$, respectively. The soil N:P at Palo Verde Marsh was low (mean $\pm \mathrm{SE}=6.9 \pm 0.5$ ) and there was no significant relationship between soil TP and Typha aboveground biomass, ramet density, or ramet height. The mean soil $\mathrm{pH}$ (in $0.01 \mathrm{~mol} / \mathrm{L} \mathrm{CaCl}_{2}$ ) was 6.5 \pm 0.1 .

\section{Seed bank}

There was no apparent impact of physical disturbance via fangueo on seed bank germinant density or richness (Fig. 3a, b). As in most wetlands, seed bank germinant density and richness under drawdown conditions was higher than under flooded conditions (Fig. 3a, b; $F_{1,41}=$ 75.3, $P<0.0001 ; F_{1,41}=51.9, P<0.0001$, respectively). The seed bank in Palo Verde Marsh was both dense and rich (Fig. 3a, b). Typha domingensis was one of the most common species in the seed bank at the site; for the drawdown treatment, the $T$. domingensis seed bank germinants accounted for $23 \%$ of the total number of germinants. The mean $T$. domingensis seed bank germinant density was $456 \pm 61$ germinants $/ \mathrm{m}^{2}$.

\section{Typha biomass, ramet architecture, recruitment, and clonal expansion}

As expected, Typha removal via fangueo resulted in a dramatic decrease in Typha aboveground biomass (ABG), ramet height, and ramet density during the first year (Fig. 4a, b, c; $F_{2,28}=229.1, P<0.0001 ; F_{2,28}=$ 704.4, $P<0.0001 ; F_{2,28}=227.5, P<0.0001$, respectively). However, post-removal Typha recruitment 

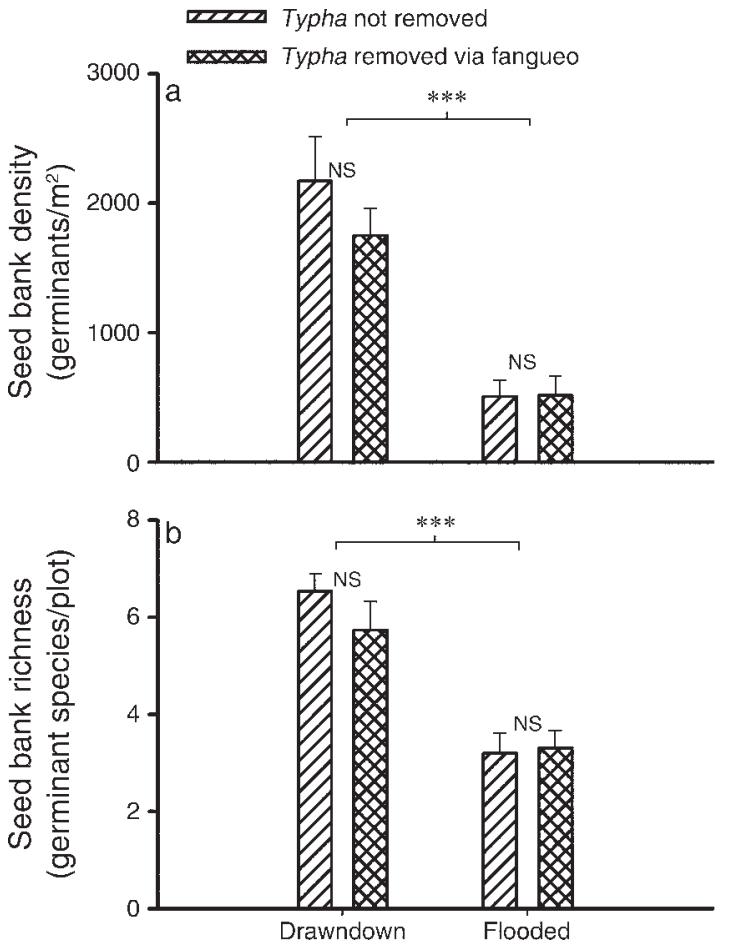

FIG. 3. Impact of mechanical disturbance (i.e., fangueo) and water level on seed bank (a) density and (b) richness (mean $+\mathrm{SE})$.

$* * * P<0.001$

and growth at the site was high (Fig. 4a, b, c) and resulted in significant increases in Typha ABG, height, and density in the Typha-removed plots ( $\mathrm{F}$ and FF treatment levels) in the second year (Fig. $4 \mathrm{a}, \mathrm{b}, \mathrm{c} ; F_{1,42}=$ $13.9, P<0.001 ; F_{1,42}=21.5, P<0.0001 ; F_{1,42}=14.7, P$ $<0.001$, respectively). Despite this increase, Typha ABG, height, and density in the Typha-removed plots in the second year were still lower than in the control plots (Fig. 4a, b, c; $F_{2,28}=43.3, P<0.0001, F_{2,28}=76.9$, $P<0.0001 ; F_{2,28}=24.5, P<0.0001$, respectively). Throughout the study, there was no significant difference between the two Typha-removed treatment levels (F and FF) in Typha ABG, height, or density (Fig. $4 \mathrm{a}, \mathrm{b}, \mathrm{c})$. Most of the mature Typha stands in our study area were between 2 and $4 \mathrm{~m}$ tall, with ramet densities typically in the 9-14 ramets $/ \mathrm{m}^{2}$ range. However, there are other sections of the Park (e.g., La Bocana Marsh) that have Typha stands with ramets that are $>5 \mathrm{~m}$ in height.

Recently germinated Typha seedlings were observed in the Typha-removed plots during the March and April 2007 vegetation surveys. Typha recruitment in these plots was highest in April 2007 with a mean of $84 \pm 20$ individuals $/ \mathrm{m}^{2}$ and a maximum of 368 individuals $/ \mathrm{m}^{2}$. Typha horizontal clonal expansion in the second year along the edge between control and fangueo plots was also high, with a mean expansion of $247 \pm 41 \mathrm{~cm} / \mathrm{yr}$ and a maximum of $571 \mathrm{~cm} / \mathrm{yr}$.

\section{Plant community}

Typha removal via fangueo resulted in higher plant species diversity (Shannon $H^{\prime}$ ) and richness (Fig. 5a, b; $F_{2,221}=162.3, P<0.0001 ; F_{2,221}=54.6, P<0.0001$, respectively). Both diversity and richness were higher during the wet-season surveys than the dry-season surveys (Fig. 5a, b; $F_{5,221}=21.0, P<0.0001 ; F_{5,221}=$ 74.0, $P<0.0001$, respectively). Throughout the study, there was no difference in plant species diversity between the two Typha-removed treatment levels (F and FF; Fig. 5a). However, the fenced plots (FF) had a slightly higher plant richness than the unfenced plots (F) (Fig. 5b; $\left.F_{1,138}=10.1, P=0.002\right)$, and this difference was greatest during the months of May and June (Fig. 5b; $F_{4,138}=$ $3.2, P=0.016)$.

There was no significant difference between the plant community composition in the Typha-removed treat-

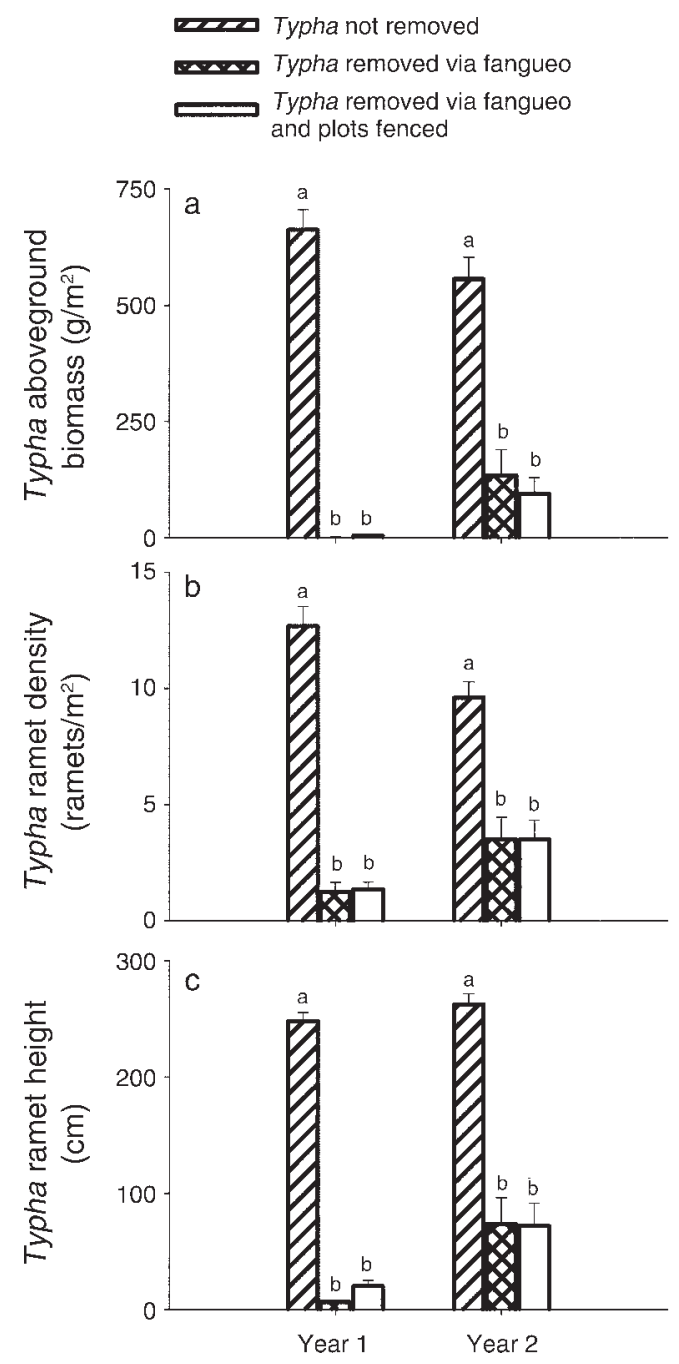

FIG. 4. Impact of Typha removal via fangueo and fenced plots on Typha (a) aboveground biomass, (b) ramet density, and (c) ramet height (mean $+\mathrm{SE}$ ). Different letters indicate significant differences between treatments within each year. 


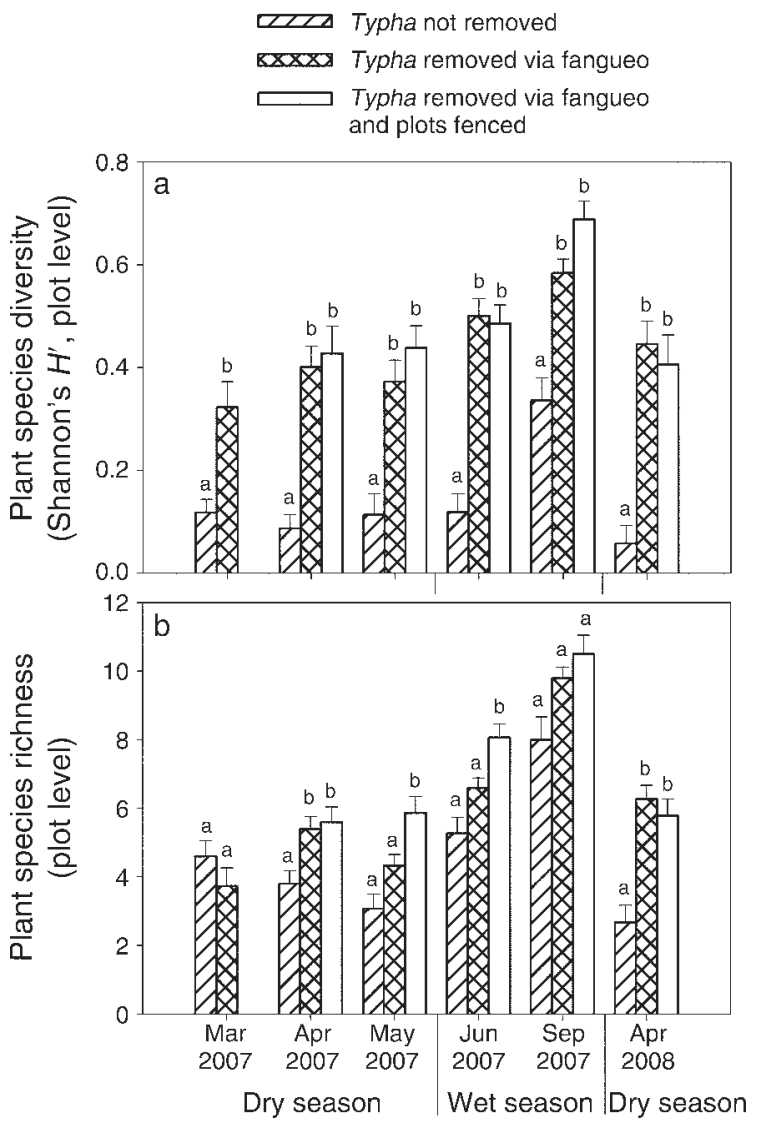

FIG. 5. Impact of Typha removal via fangueo and fenced plots on plant species (a) diversity and (b) richness (mean $+\mathrm{SE}$ ). Letters refer to comparisons between treatments within each sampling period.

ments ( $\mathrm{F}$ and $\mathrm{FF}$ ) at any single date in the study (MRPP, $A<0.02$ and insignificant $P$ for all tests; $A$ is the "chance-corrected within-group agreement" [McCune and Grace 2002]). Hence, these two treatments are illustrated as one group (Typha removed via fangueo) in the NMS ordination (Fig. 6). The proportion of the compositional variance represented by the three axes included in the analysis was 0.619 (axis 1, 0.167 ; axis $2,0.265$; and axis $3,0.187$ ). Although we tested various environmental variables (i.e., soil properties, elevation, bare ground, litter cover, water depth), water depth was the only variable we measured that was strongly correlated to the biplot axes. Water depth was most strongly correlated to the vertical biplot axis ( $\tau=$ 0.48).

As expected, the plant community in the Typha removed via fangueo plots $(\mathrm{F})$ was significantly different than in the control plots (C) immediately after fangueo (MRPP, March 2007, $A=0.28, P<0.0000001$ ) and throughout the course of this study (MRPP, April 2007, $A=0.29$; May 2007, $A=0.30$; June 2007, $A=0.27$; September 2007, $A=0.26$; April 2008, $A=0.33 ; P<$ 0.000001 for all tests). However, there was considerable temporal change in the composition found in both Typha removed via fangueo treatments ( $\mathrm{F}$ and FF), particularly in response to seasonal flooding; there was a significant difference between the wet and dry-season communities (Fig. 6; Tables 3 and 4; MRPP, dry 2007 vs. wet 2007, $A=0.06, P<0.00001$; wet 2007 vs. dry $2008, P<0.05, P<0.00001)$. In the second dry season, the composition in these plots ( $\mathrm{F}$ and FF) showed more plot-level variation than in the first year; whereas some of the plots were dominated by Hymenachne amplexicaulis, Cyperus articulatus, and Paspalum vaginatum, others were dominated by Typha (compare the locations of the $\times$ symbols in Fig. 6 with the species centroids). As expected, the Typha-control plots were strongly dominated by Typha and few other species were present in abundance in these plots (Fig. 6; Tables 3 and 4). After Typha removal, plots retained little vegetation cover until the start of the first wet season, when the freefloating and floating-rooted species Neptunia natans and Nymphaea amazonum became dominant. Several emergent species (e.g., Hymenachne amplexicaulis, Paspalum vaginatum, Typha domingensis) also became established during this period but were not dominant due to their small size. During the second dry season in these Typharemoved plots, several grass species (e.g., Hymenachne amplexicaulis and Paspalum vaginatum) and Typha all increased in importance (i.e., their importance values increased).

\section{Discussion}

Regime shifts often produce ecosystems with properties that enhance stability and resilience; as a result, ecosystem management after a regime shift is challenging and often entails the development of innovative approaches (Suding et al. 2004, Seastedt et al. 2008, Hobbs et al. 2009). Our results quantify the impact of an approach that has been used to manage a landscapescale Typha invasion in Palo Verde National Park (Costa Rica). The approach employed a form of repeated mechanical disturbance (i.e., fangueo) in combination with seasonal flooding and drought to restrict cattail expansion, create habitat heterogeneity, and maintain plant diversity.

\section{Typha resistance and resilience: implications for restoration after a regime shift}

Long-term removal of Typha is complicated by the combination of $r$ - and $K$-type strategies that enable Typha to be such a dominant, ubiquitous, resistant, and resilient genus (McNaughton 1966, 1975). Established Typha stands are highly resistant to management, and resource managers at Palo Verde Marsh experimented with various approaches (e.g., fire, manual cutting, cattle grazing) before selecting fangueo (McCoy and Rodriguez 1994). We expected that management via fangueo would rapidly reduce Typha dominance in the first year. Indeed, the fangueo treatment resulted in an immediate and large reduction in Typha aboveground 


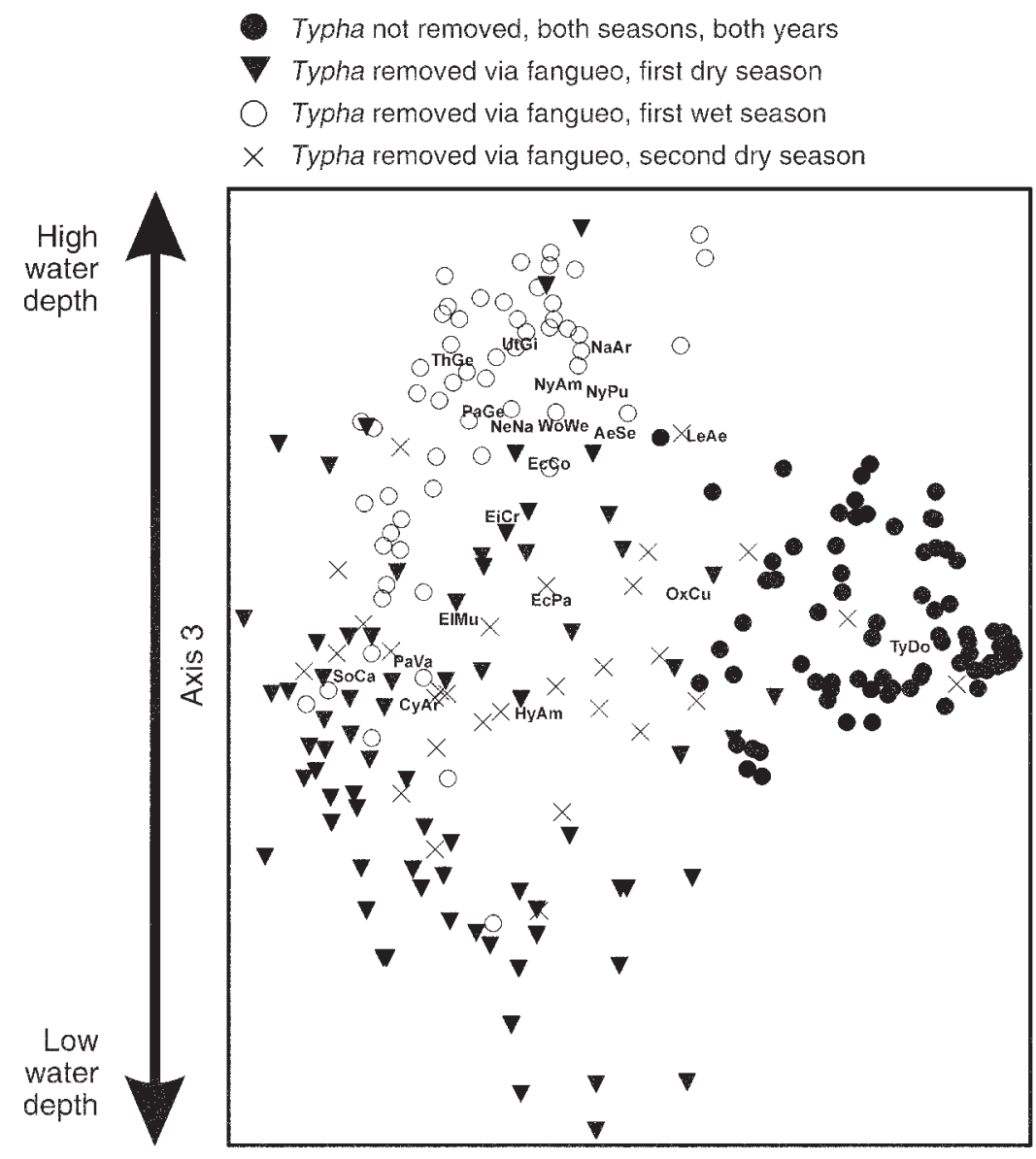

Axis 2

FIG. 6. Impact of Typha removal via fangueo and seasonal flooding on plant community composition. This is a nonmetric multidimensional scaling (NMS) ordination of individual plots in species space. Whereas the individual plot treatments are denoted by symbols, the species centroids are denoted by four-letter species codes (see Table 4). Water depth (the only environmental variable we measured with a strong correlation to ordination space) was most strongly correlated to the vertical axis.

biomass, ramet density, and ramet height. Yet we also expected that the landscape-scale expansion and establishment of monotypic Typha had enhanced cattail resilience and, that despite effective removal of cattail via fangueo in the first year, cattail would regenerate and become dominant again without repeated management. Our results indicate that Typha stands in Palo Verde Marsh are highly resistant and resilient due to tremen-

TABLE 3. Common plant species in the control and Typha-removed via fangueo plots during the dry and wet seasons.

\begin{tabular}{|c|c|c|c|}
\hline Typha not removed & & Typha removed via fangueo & \\
\hline Both seasons, both years & Dry season 2007 & Wet season 2007 & Dry season 2008 \\
\hline $\begin{array}{l}\text { Typha domingensis } \\
\left(82,89^{*}\right)\end{array}$ & $\begin{array}{l}\text { Paspalum vaginatum } \\
(2,12)\end{array}$ & $\begin{array}{l}\text { Neptunia natans } \\
\quad\left(20,65^{*}\right)\end{array}$ & $\begin{array}{l}\text { Hymenachne amplexicaulis } \\
\quad\left(13,44^{*}\right)\end{array}$ \\
\hline $\begin{array}{l}\text { Hymenachne amplexicaulis } \\
\quad(1,6)\end{array}$ & $\begin{array}{l}\text { Hymenachne amplexicaulis } \\
(2,8)\end{array}$ & $\begin{array}{l}\text { Nymphaea amazonum } \\
\left(11,72^{*}\right)\end{array}$ & $\begin{array}{l}\text { Neptunia natans } \\
\quad(6,21)\end{array}$ \\
\hline $\begin{array}{l}\text { Neptunia natans } \\
\quad(1,3)\end{array}$ & $\begin{array}{l}\text { Solanum campechiense } \\
\quad\left(1,46^{*}\right)\end{array}$ & $\begin{array}{l}\text { Utricularia gibba } \\
\qquad\left(3,44^{*}\right)\end{array}$ & $\begin{array}{l}\text { Typha domingensis } \\
\quad(6,7)\end{array}$ \\
\hline $\begin{array}{l}\text { Nymphaea amazonum } \\
(1,4)\end{array}$ & $\begin{array}{l}\text { Neptunia natans } \\
\quad(1,4)\end{array}$ & $\begin{array}{l}\text { Hymenachne amplexicaulis } \\
(3,14)\end{array}$ & $\begin{array}{l}\text { Paspalum vaginatum } \\
\quad\left(4,18^{*}\right)\end{array}$ \\
\hline $\begin{array}{l}\text { Echinodorus paniculatus } \\
\quad(0,5)\end{array}$ & $\begin{array}{l}\text { Cyperus articulatus } \\
\quad(1,13)\end{array}$ & $\begin{array}{l}\text { Paspalum vaginatum } \\
(2,11)\end{array}$ & $\begin{array}{l}\text { Eichhornia crossipes } \\
\quad\left(3,21^{*}\right)\end{array}$ \\
\hline
\end{tabular}

Notes: The five plant species with the highest importance values are shown for each of the four groups illustrated in the nonmetric multidimensional scaling (NMS) analysis (Fig. 6). Species are listed in descending rank order of importance value. The values in parentheses represent the importance value ([mean percentage cover $\times$ frequency]/100) and indicator value (percentage of perfect indication for that group; calculated using indicator species analysis, INSPAN) for each species, respectively.

* Indicator values significant at $P<0.05$. 
Table 4. Common plant species observed in Palo Verde Marsh during the course of this study.

\begin{tabular}{|c|c|c|c|c|c|}
\hline Species & Code & Life form & Species & Code & Life form \\
\hline Aeschynomene sensitiva & $\mathrm{AeSe}$ & $\mathrm{E}$ & Nymphaea amazonum & NyAm & FR \\
\hline Cyperus articulatus & CyAr & E & Nymphaea pulchella & $\mathrm{NyPu}$ & FR \\
\hline Echinochloa colona & $\mathrm{EcCo}$ & E & Oxycaryum cubense & $\mathrm{OxCu}$ & $\mathrm{E}$ \\
\hline Echinodorus paniculatus & $\mathrm{EcPa}$ & $\mathrm{E}$ & Paspalum vaginatum & $\mathrm{PaVa}$ & E \\
\hline Eichhornia crassipes & $\mathrm{EiCr}$ & FF & Paspalidium geminatum & $\mathrm{PaGe}$ & E \\
\hline Eleocharis mutata & $\mathrm{ElMu}$ & $\mathrm{E}$ & Solanum campechiense & SoCa & $\mathrm{E}$ \\
\hline Hymenachne amplexicaulis & HyAm & E & Thalia geniculata & ThGe & $\mathrm{E}$ \\
\hline Lemna aequinoctialis & LeAe & FF & Typha domingensis & TyDo & $\mathrm{E}$ \\
\hline Najas arguta & $\mathrm{NaAr}$ & $\mathrm{S}$ & Utricularia gibba & UtGi & $\mathrm{S}$ \\
\hline Neptunia natans & $\mathrm{NeNa}$ & FF & Wolffiella welwitschii & WoWe & FF \\
\hline
\end{tabular}

Notes: Each species is accompanied by a four-letter code that can be used to interpret the species centroids in the NMS ordination (Fig. 6). Common species were defined as those present in $>5 \%$ of the plots. The life form abbreviations indicate the species' predominant life form, as follows: E, emergent; FF, free-floating; FR, floating-rooted; and S, submerged.

dous growth and reproduction (both sexual and asexual) at various life history stages. First, Typha clonal expansion is rapid; the average rate of vegetative expansion of a mature Typha stand into managed areas was about $2.5 \mathrm{~m} / \mathrm{yr}$, indicating that established and clonally integrated Typha ramets are resistant to management activities and disturbances that do not lead to mortality. Second, the propagule pressure in these areas is great due to: (A) a large Typha seed bank; and (B) a large influx of wind-transported seeds from adjacent Typha stands. Typha germination and establishment rates from these propagules were high. As a result, Typha had recruited into most of the managed plots during the two years of our study. Although these seedlings grew faster than most other species, they were not yet clonally integrated, which means that their growth was slow relative to adult Typha. At the end of this study, Typha dominance in managed areas was still small relative to control areas. Yet we expect that once the seedlings produce new ramets and become clonally integrated, Typha will dominate these plots again without additional management (i.e., within 2-4 years). Currently, management via fangueo at Palo Verde Marsh is relatively cheap ( $\$ 40 /$ ha in this site) and rapid (one tractor can remove 10-16 ha of Typha per day); hence, it has been repeated on an annual basis, which has limited subsequent Typha dominance and maintained diversity.

Typha resistance to management is highly dependent upon phenology and hydrology-induced physiological stress (Linde et al. 1976, Apfelbaum 1985). At Palo Verde Marsh, fangueo has recently been implemented in the beginning to middle of the dry season, when the water level is typically $<75 \mathrm{~cm}$ in depth and receding. Since fruiting at Palo Verde Marsh occurs primarily in the dry season, we expect that Typha energy reserves should be lowest during this period. Typha store large carbohydrate energy reserves in rhizomes to produce new ramets and recover from disturbance (Linde et al. 1976). Linde et al. (1976) demonstrated the importance of planning management efforts for periods when these energy reserves are at their minimum. In addition to phenology, hydrology plays an important role during
Typha management (Apfelbaum 1985, Sojda and Solberg 1993). Wetland hydroperiod determines plant community composition and can greatly influence the dominance and resistance of cattail and other invasive wetland plants (Zedler and Kercher 2004). From a management perspective, flooding regimes can be utilized to produce anaerobic conditions and physiological stress that can decrease resistance to management (e.g., Sojda and Solberg 1993, Jenkins et al. 2008). In Palo Verde Marsh, ramets that are crushed via fangueo in the beginning of the dry season are subjected to anaerobic stress immediately after fangueo. Shortly thereafter, the water levels recede completely and any ramets that are still alive are subjected to additional physiological stress associated with drought-like conditions. Rapid flooding at the start of the rainy season due to extreme storm events can also lead to Typha mortality when young ramets are submerged and subjected to anaerobic conditions.

\section{Diversity maintained by disturbance, propagule bank, and seasonal climate}

The biotic assemblages present in tropical, seasonally flooded wetlands like Palo Verde Marsh are defined by a combination of multiple and frequent disturbances (e.g., fire, grazing) and distinct and extreme seasonal climate cycles (i.e., flooding, drought) (Middleton 1999). Community resilience in these dynamic ecosystems is dependent upon a propagule bank that enables rapid post-disturbance recovery (van der Valk 1981, Brock et al. 2003), and disturbance is often responsible for maintaining diversity (Kirkman and Sharitz 1994, Middleton 1999). Our results indicate that, after Typha removal, the abiotic filters associated with seasonal flooding and drawdown played an important role in determining plant community change and produced distinct dry and wet-season plant assemblages (Table 3; Fig. 6). During the wet season, the managed plots contained a heterogeneous mixture of plant life forms (e.g., free-floating, floating-rooted, submerged, and emergent). As the water level declined throughout the dry season, the free-floating and floating-rooted species became less abundant. The propagule bank at Palo 
Verde Marsh was relatively large and diverse, which enabled post-disturbance regeneration and a rapid increase in plant diversity after Typha management via fangueo.

In addition to plant diversity, avian diversity at Palo Verde Marsh has been shown to rapidly increase in response to Typha management via fangueo (see McCoy and Rodriguez 1994, Trama 2005). Restoring avian diversity has continuously been one of the primary objectives associated with the various management efforts to restrict Typha expansion at Palo Verde Marsh. We conducted an avian survey in a subset of our experimental treatments in order to coarsely gauge the short-term and immediate avian response. These surveys indicated a 98- and 5-fold increase in avian density and richness, respectively, in response to Typha management via fangueo (M. J. Osland, personal observation).

Based upon our results and the literature, we present a conceptual model that illustrates the role of repeated disturbance (i.e., fangueo) and seasonal hydrologic fluctuations for reducing Typha dominance and increasing plant and avian diversity at Palo Verde Marsh (Fig. 7; adapted from successional models developed for temperate and tropical marshes [van der Valk 1981, Middleton 1999]). Without disturbance, Typha dominance rapidly increases and plant and avian diversity decrease due to competitive exclusion and reduced habitat heterogeneity, respectively. Repeated disturbances (e.g., fangueo) and seasonal hydrologic fluctuations (e.g., flooding and drawdown) reduce Typha dominance and enable plant recruitment from the propagule bank, which results in greater habitat heterogeneity and plant and avian diversity. We suggest that this model is likely applicable to various tropical dry wetlands across the globe where the historical disturbance regime has been altered and monotypic clonal plant invasions have occurred.

\section{Heavy machinery use during restoration: potential impacts on soil properties and seedling emergence}

The use of heavy machinery during restoration can be detrimental to soil properties and soil-regulated biotic processes (Lowery and Schuler 1991, Kozlowski 1999). Fangueo is a form of mechanical disturbance that at Palo Verde Marsh entails the use of a tractor. Hence, we hypothesized that fangueo would result in compaction (i.e., higher soil bulk densities relative to areas that did not receive the fangueo treatment). We also expected that the mechanical disturbance associated with fangueo would have an impact on the seed bank and alter the pool of plant species that germinate from the seed bank. However, we found no apparent short-term impact of fangueo on soil bulk density or seed bank germinant composition. Importantly, fangueo had no short-term impact on any of the soil properties we measured. The soil bulk density in Palo Verde Marsh is relatively high compared to many other wetlands, particularly wetlands with highly organic soils and low soil bulk densities. Tractor use in wetlands with low soil bulk densities is not advised, because it would likely result in long-lasting physical and ecological change, and also probably be risky for tractor operators due to high soil instability. We note that we were not able to measure plant available inorganic nitrogen, which is often elevated after disturbances that remove plant biomass (Schlesinger 1997, Richardson 2008b). We also stress that our soil analyses assess the short-term impact of the mechanical disturbance and not the long-term impact of Typha removal.

\section{Linkages between nutrient inputs and landscape-scale Typha expansion}

In many tropical and subtropical wetlands, elevated phosphorus (P) inputs have been linked to landscapescale Typha expansions (Craft and Richardson 1997, Johnson and Rejmánková 2005, Hagerthey et al. 2008). Typha dominance is unlikely in wetlands with low $\mathrm{P}$ availability and high N:P ratios (Richardson et al. 1999, Debusk et al. 2001, Craft and Richardson 2008). Most published biogeochemical investigations in Central American wetlands have been conducted in the uniquely oligotrophic, calcareous, and P-limited wetlands of the Yucatan Peninsula (Rejmánková et al. 1996, Rejmánková 2001) and a P-limited coastal mire in Panama (Troxler 2007). The results from these studies and the Everglades region of Florida (Davis 1994, Richardson et al. 1999, Noe et al. 2001) are occasionally extrapolated to all wetlands in the region to imply that most Central American wetlands may be $\mathrm{P}$ limited. However, the low soil $\mathrm{N}: \mathrm{P}$ ratios (mean $\pm \mathrm{SE}=6.9 \pm$ $0.5)$ found here indicate that Palo Verde Marsh and other wetlands in the region may be N-limited. Typha foliar N:P measurements from another wetland in PVNP (La Bocana Marsh) are also indicative of nitrogen limitation $(7.6 \pm 0.2$; mean $\pm \mathrm{SE}$ ) (see the following for discussion of wetland $\mathrm{N}: \mathrm{P}$ ratios and nutrient limitation: Koerselman and Meuleman 1996, Verhoeven et al. 1996, Bedford et al. 1999, Güsewell et al. 2003). The nutrient-induced expansion of Typha in the Everglades region may be the most infamous and extensively studied regime shift that has occurred in freshwater wetland ecosystems (see Gunderson 2001, Hagerthey et al. 2008, Richardson 2008b). As a result, specific soil eutrophication thresholds have been identified and have been used to elucidate landscape-scale plant community transformations. We note that, on a volume basis, the mean soil $\mathrm{P}$ concentration at Palo Verde Marsh $\left(530 \mu \mathrm{g} \mathrm{P} / \mathrm{cm}^{3}\right)$ is far above the identified threshold for Typha invasion in the Everglades, which is $\sim 50 \mu \mathrm{g} \mathrm{P} / \mathrm{cm}^{3}$ [calculated using a bulk density of $0.1 \mathrm{~g} /$ $\mathrm{cm}^{3}$ (Craft and Richardson 2008) and a mass-basis threshold of $500 \mathrm{mg} \mathrm{P} / \mathrm{kg}$ (Richardson et al. 1999, Debusk et al. 2001, Craft and Richardson 2008, Hagerthey et al. 2008)]. These comparisons are important because they characterize the potential for Typha 


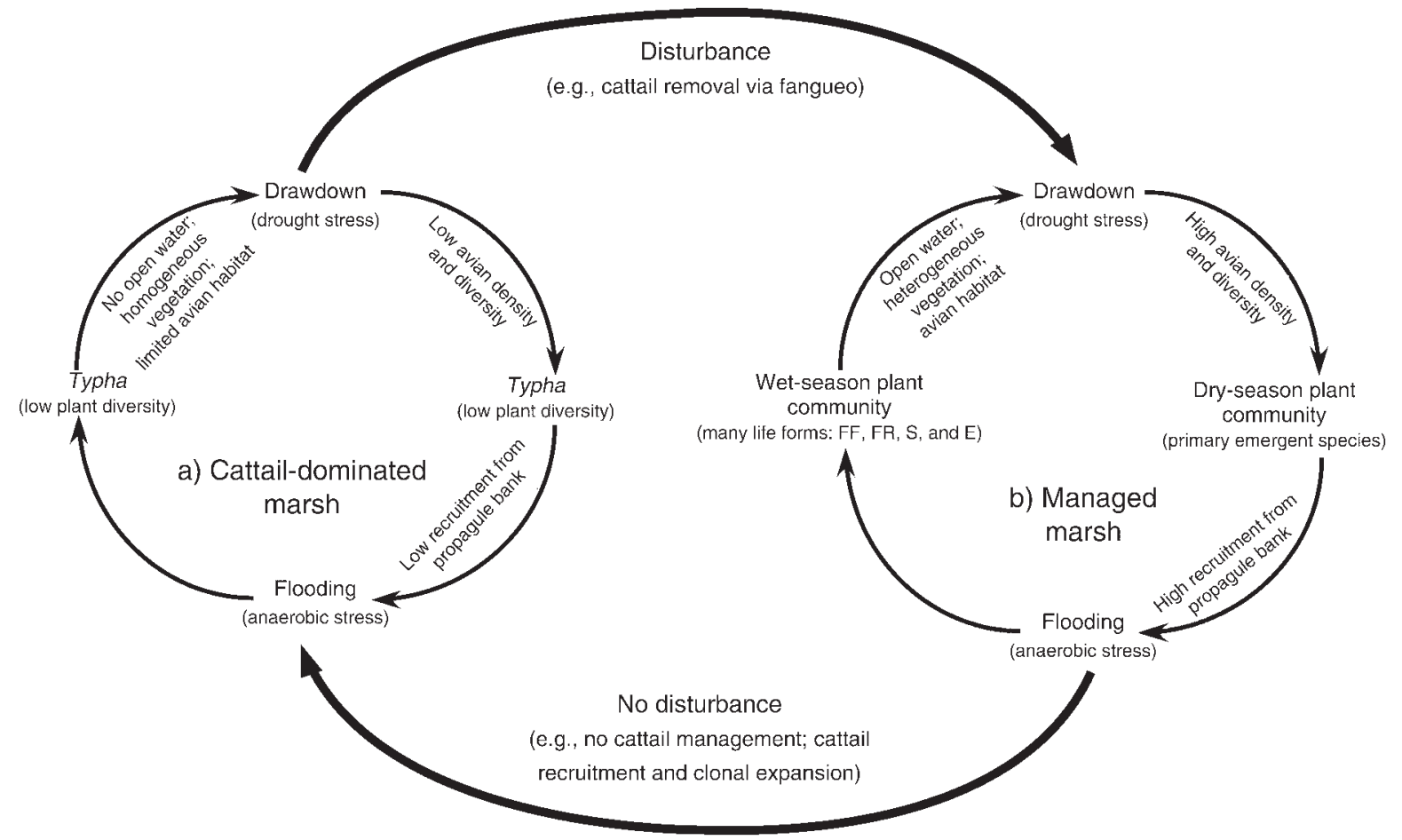

FIG. 7. A conceptual model illustrating the role of repeated disturbance and seasonality for maintaining diversity at Palo Verde Marsh (adapted from van der Valk [1981] and Middleton [1999]). The model includes two marsh categories: (a) the highly resistant Typha-dominated marsh and (b) the seasonal and heterogeneous managed marsh. Note that the managed marsh is not a steady state; after 2-4 years without disturbance, high Typha recruitment and clonal expansion will lead to Typha dominance. Frequent disturbances (e.g., repeated fangueo, grazing, flooding) are required to limit Typha dominance, create space for plant recruitment from the propagule bank, and maintain the seasonal plant and avian communities found in the managed marsh. Plant life form abbreviations are: FF, free-floating; FR, floating-rooted; S, submerged; E, emergent.

dominance in Palo Verde Marsh and highlight the distinct biogeochemical differences between tropical dry wetlands like Palo Verde Marsh and the P-limited tropical peatlands that have been studied in the Everglades, the Caribbean coast of Belize, and the Caribbean coast of Panama.

\section{Summary}

In wetlands across the globe, anthropogenically induced regime shifts in the form of clonal plant invasions (e.g., Typha, Phragmites, Phalaris) are becoming increasingly common and have resulted in diversity loss and altered wetland conditions (Zedler and Kercher 2004, Hagerthey et al. 2008). Since the monodominant ecosystems that are produced during such transformations are often highly resistant to management and restorative efforts, there has been much interest in approaches that can be used to reduce the dominance of these species and maintain diversity. In this study, we quantified the impact of an approach that has been used at a local scale in northwestern Costa Rica to increase wetland diversity after a rapid landscape-scale Typha expansion. The approach uses a novel form of disturbance (i.e., fangueo) in combination with seasonal hydrology to reduce resistance to management, create habitat heterogeneity, and maintain diversity.

\section{ACKNOWLEDGMENTS}

We are grateful to A. Osland, A. McHugh, A. Blanco Sibaja, and D. González for their assistance both in the field and lab. G. Murillo provided valuable logistical assistance. The soil and vegetation analyses were improved by the help of W. Willis, P. Heine, and M. Ho. The hydrology and climate data were obtained from OTS records with the assistance of J. Serrano and W. Lopez. We appreciate the support provided by OTS and MINAE. N. González provided the assistance needed to implement the fangueo treatments. A. Daniels, S. Hall, J. Sexton, A. Sutton-Grier, C. Wigand, and two anonymous reviewers provided valuable comments on earlier drafts of the manuscript. This study was conducted with the support of a Fulbright Fellowship, an NSF IRES Grant, an OTS Research Fellowship, a Duke University Graduate School PreDissertation Research Travel Award, a Duke University Provost's Pre-Dissertation International Field Research Grant, and the Duke Wetland Center Case Studies Endowment. The information in this document has been subjected to review by the U.S. Environmental Protection Agency National Health and Environmental Effects Research Laboratory and approved for publication. Approval does not signify that the contents reflect the views of the Agency, nor does mention of trade names or commercial products constitute endorsement or recommendation for use. This is contribution number 1383 from the Gulf Ecology Division. 


\section{Literature Cited}

Apfelbaum, S. I. 1985. Cattail (Typha spp.) management. Natural Areas Journal 5:9-17.

Bakker, J. P., and F. Berendse. 1999. Constraints in the restoration of ecological diversity in grassland and heathland communities. Trends in Ecology and Evolution 14:63-68.

Bedford, B. L., M. R. Walbridge, and A. Aldous. 1999. Patterns in nutrient availability and plant diversity of temperate North American wetlands. Ecology 80:2151-2169.

Bray, J. R., and J. T. Curtis. 1957. An ordination of the upland forest communities of southern Wisconsin. Ecological Monographs 27:325-349.

Brock, M. A., D. L. Nielsen, R. J. Shiel, J. D. Green, and J. D. Langley. 2003. Drought and aquatic community resilience: the role of eggs and seeds in sediments of temporary wetlands. Freshwater Biology 48:1207-1218.

Burnidge, W. S. 2000. Cattle and the management of freshwater neotropical wetlands in Palo Verde National Park, Guanacaste, Costa Rica. Thesis. University of Michigan, Ann Arbor, Michigan, USA.

Collins, S. L., A. K. Knapp, J. M. Briggs, J. M. Blair, and E. M. Steinauer. 1998. Modulation of diversity by grazing and mowing in native tallgrass prairie. Science 280:745-747.

Craft, C. B., and C. J. Richardson. 1997. Relationships between soil nutrients and plant species composition in Everglades peatlands. Journal of Environmental Quality 26:224-232.

Craft, C. B., and C. J. Richardson. 2008. Soil characteristics of the Everglades peatland. Pages 59-72 in C. J. Richardson, editor. The Everglades experiments: lessons for ecosystem restoration. Springer-Verlag, New York, New York, USA.

Daniels, A. E., and G. S. Cumming. 2008. Conversion or conservation? Understanding wetland change in northwest Costa Rica. Ecological Applications 18:49-63.

Davis, S. M. 1994. Phosphorus inputs and vegetation sensitivity in the Everglades. Pages 357-378 in S. M. Davis and J. C. Ogden, editors. Everglades: the ecosystem and its restoration. St. Lucie Press, Delray Beach, Florida, USA.

Debusk, W. F., S. Newman, and K. R. Reddy. 2001. Spatiotemporal patterns of soil phosphorus enrichment in Everglades Water Conservation Area 2A. Journal of Environmental Quality 30:1438-1446.

Dufrene, M., and P. Legendre. 1997. Species assemblages and indicator species: the need for a flexible asymmetrical approach. Ecological Monographs 67:345-366.

Farrer, E. C., and D. E. Goldberg. 2009. Litter drives ecosystem and plant community changes in cattail invasion. Ecological Applications 19:398-412.

Folke, C., S. Carpenter, B. Walker, M. Scheffer, T. Elmqvist, L. Gunderson, and C. S. Holling. 2004. Regime shifts, resilience, and biodiversity in ecosystem management. Annual Review of Ecology, Evolution, and Systematics 35:557-581.

Galatowitsch, S. M., N. O. Anderson, and P. D. Ascher. 1999. Invasiveness in wetland plants in temperate North America. Wetlands 19:733-755.

Gerard, M., M. El Kahloun, J. Rymen, O. Beauchard, and P. Meire. 2008. Importance of mowing and flood frequency in promoting species richness in restored floodplains. Journal of Applied Ecology 45:1780-1789.

González, E. 2002. Restauración y manejo del Humedal Palo Verde, un Sitio Ramsar en el Registro de Montreux de humedales en peligro. Organization for Tropical Studies, San Pedro, Costa Rica.

Grootjans, A. P., J. P. Bakker, A. J. M. Jansen, and R. H. Kemmers. 2002. Restoration of brook valley meadows in the Netherlands. Hydrobiologia 478:149-170.

Gunderson, L. H. 2001. Managing surprising ecosystems in southern Florida. Ecological Economics 37:371-378.

Güsewell, S., W. Koerselman, and J. T. A. Verhoeven. 2003. Biomass N:P ratios as indicators of nutrient limitation for plant populations in wetlands. Ecological Applications 13:372-384.

Hagerthey, S. E., S. Newman, K. Rutchey, E. P. Smith, and J. Godin. 2008. Multiple regime shifts in a subtropical peatland: community-specific thresholds to eutrophication. Ecological Monographs 78:547-565.

Hall, S. J. 2009. Cultural disturbances and local ecological knowledge mediate cattail (Typha domingensis) invasion in Lake Pátzcuaro, México. Human Ecology 37:241-249.

Hall, S. J., R. Lindig-Cisneros, and J. B. Zedler. 2008. Does harvesting sustain plant diversity in Central Mexican wetlands? Wetlands 28:776-792.

Hendershot, W. H., and H. Lalande. 1993. Soil reaction and exchangeable acidity. Pages 141-145 in M. R. Carter, editor. Soil sampling and methods of analysis. Canadian Society of Soil Science, Lewis Publishers, London.

Hobbs, R. J., E. Higgs, and J. A. Harris. 2009. Novel ecosystems: implications for conservation and restoration. Trends in Ecology and Evolution 24:599-605.

Hobbs, R. J., and K. N. Suding. 2009. New models for ecosystem dynamics and restoration. Island Press, Washington, D.C., USA.

Holdridge, L. R. 1967. Life zone ecology. Tropical Science Center, San Jose, Costa Rica.

Jenkins, N. J., J. A. Yeakley, and E. M. Stewart. 2008. Firstyear responses to managed flooding of lower Columbia River bottomland vegetation dominated by Phalaris arundinacea. Wetlands 28:1018-1027.

Jiménez, J. A., E. González, and J. Calvo. 2003. Recomendaciones técnicas para la restauración hidrológica del Parque Nacional Palo Verde. Organization for Tropical Studies, San Jose, Costa Rica.

Johnson, S., and E. Rejmánková. 2005. Impacts of land use on nutrient distribution and vegetation composition of freshwater wetlands in northern Belize. Wetlands 25:89-100.

Karam, A. 1993. Chemical properties of organic soils. Pages 459-471 in M. R. Carter, editor. Soil sampling and methods of analysis. Canadian Society of Soil Science, Lewis Publishers, London, UK.

Kirkman, L. K., and R. R. Sharitz. 1994. Vegetation disturbance and maintenance of diversity in intermittently flooded Carolina bays in South Carolina. Ecological Applications 4:177-188.

Koerselman, W., and A. F. M. Meuleman. 1996. The vegetation $N: P$ ratio: a new tool to detect the nature of nutrient limitation. Journal of Applied Ecology 33:14411450.

Kostecke, R. M. 2002. Effects of cattail management on invertebrate production and migratory bird use of Cheyenne Bottoms, KS. Dissertation. Texas Tech University, Lubbock, Texas, USA.

Kozlowski, T. T. 1999. Soil compaction and growth of woody plants. Scandinavian Journal of Forest Research 14:596-619.

Kruskal, J. B. 1964. Multidimensional scaling by optimizing goodness of fit to a nonmetric hypothesis. Psychometrika 29:1-27.

Linde, A. F., T. Janisch, and D. Smith. 1976. Cattail: the significance of its growth, phenology and carbohydrate storage to its control and management. Wisconsin Department of Natural Resources Technical Bulletin 94, Madison Wisconsin, USA.

Loaiciga, H. A., and T. H. Robinson. 1995. Sampling of agrochemicals for environmental assessment in rice paddies: dry tropical wetlands, Costa Rica. Ground Water Monitoring and Remediation 15:107-118.

Lowery, B., and R. T. Schuler. 1991. Temporal effects of subsoil compaction on soil strength and plant growth. Soil Science Society of America Journal 55:216-223.

MacDougall, A. S., and R. Turkington. 2005. Are invasive species the drivers or passengers of change in degraded ecosystems? Ecology 86:42-55. 
Maron, J. L., and R. L. Jefferies. 2001. Restoring enriched grasslands: effects of mowing on species richness, productivity, and nitrogen retention. Ecological Applications 11:10881100.

Mateo-Vega, J. 2001. Características generales de la cuenca del Río Tempisque. Pages 32-72 in J. A. Jiménez and E. González, editors. La cuenca del Río Tempisque: perspectivas para un manejo integrado. Organization for Tropical Studies, San Jose, Costa Rica.

Mather, P. M. 1976. Computational methods of multivariate analysis in physical geography. John Wiley and Sons, London, UK.

McCoy, M. B., and J. M. Rodriguez. 1994. Cattail (Typha domingensis) eradication methods in the restoration of a tropical, seasonal, freshwater marsh. Pages 469-482 in W. J. Mitsch, editor. Global wetlands: old world and new. Elsevier Science, Amsterdam, The Netherlands.

McCune, B., and J. B. Grace. 2002. Analysis of ecological communities. MjM Software Design, Gleneden Beach, Oregon, USA.

McCune, B., and M. J. Medford. 1999. PC-ORD. Multivariate analysis of ecological data, Version 4. MjM Software Design, Gleneden Beach, Oregon, USA.

McGill, W. B., and C. T. Figueiredo. 1993. Total nitrogen. Pages 201-211 in M. R. Carter, editor. Soil sampling and methods of analysis. Canadian Society of Soil Science, Lewis Publishers, London, UK.

McNaughton, S. J. 1966. Ecotype function in the Typha community-type. Ecological Monographs 36:297-325.

McNaughton, S. J. 1975. $r$ - and $K$-selection in Typha. American Naturalist 109:251-261.

Miao, S. L., E. Sindhøj, and C. Edelstein. 2008. Allometric relationships of field populations of two clonal species with contrasting life histories, Cladium jamaicense and Typha domingensis. Aquatic Botany 88:1-9.

Middleton, B. 1999. Succession and herbivory in monsoonal wetlands. Wetlands Ecology and Management 6:189-202.

Murphy, J., and J. P. Riley. 1962. A modified single solution method for the determination of phosphate in natural waters. Analytica Chimica Acta 27:31-36.

Nelson, N. F., and R. H. Dietz. 1966. Cattail control methods in Utah. Utah Department of Fish and Game Publication $66: 1-31$.

Noe, G. B., D. L. Childers, and R. D. Jones. 2001. Phosphorus biogeochemistry and the impact of phosphorus enrichment: why is the Everglades so unique? Ecosystems 4:603-624.

O'Halloran, I. P. 1993. Total and organic phosphorus. Pages 213-229 in M. R. Carter, editor. Soil sampling and methods of analysis. Canadian Society of Soil Science, Lewis Publishers, London, UK.

Peters, G. 2001. La cuenca del Tempisque: una perspectiva historica. Pages 1-21 in J. A. Jiménez and E. González, editors. La Cuenca del Río Tempisque: perspectivas para un manejo integrado. Organization for Tropical Studies, San Jose, Costa Rica.

Powers, J. S., J. M. Becknell, J. Irving, and D. Pérez-Aviles. 2009. Diversity and structure of regenerating tropical dry forests in Costa Rica: geographic patterns and environmental drivers. Forest Ecology and Management 258:959-970.

Rejmánková, E. 2001. Effect of experimental phosphorus enrichment on oligotrophic tropical marshes in Belize, Central America. Plant and Soil 236:33-53.

Rejmánková, E., K. O. Pope, R. Post, and E. Maltby. 1996. Herbaceous wetlands of the Yucatan Peninsula: communities at extreme ends of environmental gradients. Internationale Revue der gesamten Hydrobiologie und Hydrographie 81:223-252.

Richardson, C. J. 2008a. An ecological approach for the restoration of the Everglades fen. Pages 621-642 in C. J. Richardson, editor. The Everglades experiments: lessons for ecosystem restoration. Springer-Verlag, New York, New York, USA.

Richardson, C. J. 2008b. The Everglades experiments: lessons for ecosystem restoration. Springer-Verlag, New York, New York, USA.

Richardson, C. J., G. M. Ferrell, and P. Vaithiyanathan. 1999. Nutrient effects on stand structure, resorption efficiency, and secondary compounds in Everglades sawgrass. Ecology 80:2182-2192.

Sarmah, A. K., U. Pillai-McGarry, and D. McGarry. 1996. Repair of the structure of a compacted Vertisol via wet/dry cycles. Soil and Tillage Research 38:17-33.

SAS. 2004. SAS version 9.1.3. SAS Institute, Cary, North Carolina, USA.

Scheffer, M., and S. R. Carpenter. 2003. Catastrophic regime shifts in ecosystems: linking theory to observation. Trends in Ecology and Evolution 18:648-656.

Schlesinger, W. H. 1997. Biogeochemistry: an analysis of global change. Academic Press, San Diego, California, USA.

Seastedt, T. R., R. J. Hobbs, and K. N. Suding. 2008. Management of novel ecosystems: are novel approaches required? Frontiers in Ecology and the Environment 6:547553.

Sojda, R. S., and K. L. Solberg. 1993. Management and control of cattails. U.S. Fish and Wildlife Service Fish and Wildlife Leaflet 13.4.13, Washington, D.C., USA.

Sommers, L. E., R. F. Harris, J. D. H. Williams, D. E. Armstrong, and J. K. Syers. 1970. Determination of total organic phosphorus in lake sediments. Limnology and Oceanography 15:301-304.

Suding, K. N., K. L. Gross, and G. R. Houseman. 2004. Alternative states and positive feedbacks in restoration ecology. Trends in Ecology and Evolution 19:46-53.

Tiessen, H., and J. O. Moir. 1993. Total and organic carbon. Pages 187-199 in M. R. Carter, editor. Soil sampling and methods of analysis. Canadian Society of Soil Science, Lewis Publishers, London, UK.

Trama, F. A. 2005. Manejo activo y restauración del Humedal Palo Verde: cambios en las coberturas de vegetación y respuesta de las aves acuáticas. Thesis. Universidad Nacional de Costa Rica, Heredia, Costa Rica.

Trama, F. A., F. L. Rizo-Patrón, A. Kumar, E. González, D. Somma, and M. B. McCoy. 2009. Wetland cover types and plant community changes in response to cattail-control activities in the Palo Verde Marsh, Costa Rica. Ecological Restoration 27:278-289.

Travis, S. E., J. E. Marburger, S. Windels, and B. Kubátová. 2010. Hybridization dynamics of invasive cattail (Typhaceae) stands in the Western Great Lakes Region of North America: a molecular analysis. Journal of Ecology 98:7-16.

Troxler, T. G. 2007. Patterns of phosphorus, nitrogen and $\delta^{15} \mathrm{~N}$ along a peat development gradient in a coastal mire, Panama. Journal of Tropical Ecology 23:683-691.

Tuchman, N. C., D. J. Larkin, P. Geddes, R. Wildova, K. J. Jankowski, and D. E. Goldberg. 2009. Patterns of environmental change associated with Typha x glauca invasion in a Great Lakes coastal wetland. Wetlands 29:964-975.

Vaccaro, L. E., B. L. Bedford, and C. A. Johnston. 2009. Litter accumulation promotes dominance of invasive species of cattails (Typha spp.) in Lake Ontario wetlands. Wetlands 29:1036-1048.

van der Valk, A. G. 1981. Succession in wetlands: a Gleasonian approach. Ecology 62:688-696.

Verhoeven, J. T. A., W. Koerselman, and A. F. M. Meuleman. 1996. Nitrogen- or phosphorus-limited growth in herbaceous, wet vegetation: relations with atmospheric inputs and management regimes. Trends in Ecology and Evolution 11:494-497.

Zedler, J. B., and S. Kercher. 2004. Causes and consequences of invasive plants in wetlands: opportunities, opportunists, and outcomes. Critical Reviews in Plant Sciences 23:431-452. 